\title{
AlAs AS A Bi BLOCKING BARRIER IN GaAsBi MULTI-QUANTUM WELLS: STRUCTURAL ANALYSIS
}

\author{
R. Butkutè ${ }^{a}$, M. Skapas ${ }^{b}$, A. Selskis ${ }^{b}$, V. Bukauskas ${ }^{a}$, S. Stanionytè ${ }^{a, b}$, and G. Niaura ${ }^{c}$ \\ ${ }^{a}$ Department of Optoelectronics, Center for Physical Sciences and Technology, Sauletekio 3, LT-10257 Vilnius, Lithuania \\ ${ }^{\mathrm{b}}$ Department of Characterization of Materials Structure, Center for Physical Sciences and Technology, Sauletekio 3, \\ LT-10257 Vilnius, Lithuania \\ 'Department of Organic Chemistry, Center for Physical Sciences and Technology, Sauletekio 3, LT-10257 Vilnius, Lithuania \\ E-mail: renata.butkute@ftmc.lt
}

Received 29 November 2016; revised 2 January 2017; accepted 16 March 2017

\begin{abstract}
Crystallographic properties of AlAs barriers in GaAsBi-based multi-quantum well structures grown on GaAs substrates by molecular beam epitaxy (MBE) and migration-enhanced epitaxy (MEE) were studied. The quantum wells were grown at temperatures ranging from 160 to $350^{\circ} \mathrm{C}$. The width of GaAsBi quantum wells varied from 4 to $20 \mathrm{~nm}$. The optimization of technological parameters for the growth of high crystalline quality AlAs barriers at low temperatures was performed. To explore the impact of high temperature treatment on crystal quality, surface roughness and chemical composition stability, ex situ rapid thermal annealing was performed at $650-750{ }^{\circ} \mathrm{C}$ for $180 \mathrm{~s}$ in nitrogen ambiance. The structural quality of AlAs barriers, the morphology and sharpness of the interfaces between GaAsBi quantum wells and AlAs barriers were studied by high resolution X-ray diffraction, atomic force microscopy and high resolution transmission electron microscopy, respectively. In this study it was demonstrated that MEE allows one to achieve higher crystal quality of AlAs barriers at much lower temperatures in comparison to MBE. The blocking of Bi out-diffusion from the GaAsBi quantum wells toward the surface was shown for both MBE and MEE grown AlAs barriers.
\end{abstract}

Keywords: molecular beam epitaxy, migration-enhanced epitaxy, quantum structures, high resolution X-ray diffraction, atomic force microscopy, high resolution transmission electron microscopy, Raman spectroscopy

PACS: 81.15.Hi, 61.05.cp, 68.37.Ps, 68.37.Og, 82.80.Gk

\section{Introduction}

III-V semiconducting alloys containing a dilute amount of bismuth, namely, $\mathrm{GaAsBi}$, are very attractive due to the large band-gap reduction with a relatively small Bi content. Substitution of As by $\mathrm{Bi}$ in the GaAs lattice produces a much larger reduction in the band gap ( -60 to $-80 \mathrm{meV} / \% \mathrm{Bi}$ ) [1], 2] than alloying by $\mathrm{In}(-12 \mathrm{meV} / \% \mathrm{In})$ and $\mathrm{Sn}(-20 \mathrm{meV} / \%)$. Also, $\mathrm{Bi}$ is the heaviest nonradioactive element; therefore, it has a large spin orbit splitting, which is useful for spin-based semiconductor devices. It is demonstrated in [3] that the GaAsBi layer containing more than $10 \% \mathrm{Bi}$ grown on the GaAs substrate shows the photoluminescence (PL) at $1.5 \mu \mathrm{m}$ wavelengths. Even longer PL wavelengths can be achieved for the quaternary GaInAsBi compound on the InP substrate [ 4 , 5. This feature makes bismides promising materials for applications in semiconductor lasers emitting at room temperature in the mid-infrared spectral range where the fundamental absorption bands of many molecular species are located.

The peculiarities of bismides growth are related to the strong tendency of Bi segregation, which leads to the formation of droplets on the surface. Consequently, under standard GaAs growth conditions (high substrate temperature $\sim 600^{\circ} \mathrm{C}$ and non-stoichiometric As-rich ambiance) $\mathrm{Bi}$ is not embedded in the GaAs lattice, but acts as a surfactant with associated improvements in surface quality. To incorporate $\mathrm{Bi}$, growth temperatures below $400{ }^{\circ} \mathrm{C}$ and $\mathrm{As}_{2} / \mathrm{Ga}$ flux ratios close to unity are necessary. Despite the obtained achievements in optimization of technology, applications of bismides are held back by practical difficulties in growth of bulk layers and multi-quantum wells with larger than $6 \% \mathrm{Bi}$. Bi surface segregation in thick bismide layers leads to a final layered structure with several layers and different Bi content 
independent of substrate temperature and growth rate. In the case of quantum wells (QWs), the depletion of GaAs barriers occurs when the QW width is increased [6]. It is demonstrated in [6] that this process in $\mathrm{GaAsBi} / \mathrm{GaAs}$ quantum well structures is assisted by strong and complex Bi surface segregation, implying both lateral and vertical mass transport.

Our previous investigations of GaAsBi layers and $\mathrm{GaAs} / \mathrm{GaAsBi}$ multi-structures have shown that temperatures higher than $650{ }^{\circ} \mathrm{C}$ induce the movement of $\mathrm{Bi}$ and stimulate the enhancement of photoluminescence at wavelengths ranging from 1300 to $1500 \mathrm{~nm}$ 浔, 8]. The high resolution transmission electron microscopy (HRTEM) study of the crosssection of GaAsBi QWs separated by GaAs barriers showed the Bi segregation process and distortion of the multi-QW (MQW) structure through complete vanishing of interfaces between wells and barriers [8]. Nevertheless, the sharp heterointerfaces and abrupt profiles are essential for the realization of quantum heterostructure devices. In order to obtain a highquality heterostructure, the segregation of Bi should be suppressed. The interdiffusion of compositional atoms was investigated at the heterointerface between a GaAs epilayer and a $\mathrm{Ge}(111)$ substrate by secondary ion mass spectroscopy [9, 10]. It is demonstrated that when a thin AlAs layer is applied initially, diffusion of Ge into the GaAs epilayer is suppressed effectively. An abrupt heterointerface was successfully realized. A detailed study [10] of a series of samples with various AlAs interfacial layer thicknesses discovered the effectiveness of the AlAs layer at relatively high temperature growth (about $650^{\circ} \mathrm{C}$ ). The authors demonstrated that the thickness of AlAs could be reduced to $10 \mathrm{~nm}$ without affecting its effectiveness in blocking the cross diffusion of $\mathrm{Ge}, \mathrm{Ga}$ and As atoms between the layer and the substrate.

In this study we were focused on the growth and investigation of AlAs barriers in GaAsBi-based MQW structures for blocking of Bi segregation toward the surface. In our specific case the challenge was the adjustment and optimization of growth parameters of high crystalline quality AlAs barriers for low temperatures (LT) necessary to grow bismides containing more than $6 \% \mathrm{Bi}$. The structural properties of AlAs barriers were studied in detail. The main attention was paid to the impact of growth temperature, growth mode and barrier thickness on AlAs crystalline properties and the sharpness of interfaces between AlAs and GaAsBi. In situ high temperature annealing and ex situ annealing in a rapid thermal annealing oven were performed to investigate the crystal quality, surface morphology and chemical composition stability.

\section{Growth of multi-quantum wells}

GaAsBi/AlAs MQWs were grown using a SVT-A molecular beam epitaxy (MBE) reactor equipped with metallic $\mathrm{Ga}, \mathrm{Al}, \mathrm{Bi}$ sources and a two-zone cracker source to produce $\mathrm{As}_{2}$. The samples were grown by standard MBE growth and using migration-enhanced epitaxy. In the standard MBE during the growth, the flux of group III atoms is exposed contemporaneously with the flux of group $\mathrm{V}$ atoms. Meanwhile during migration-enhanced epitaxy (MEE), the atoms of group III and V are supplied in sequence: the group III atoms growing QWs and barriers are supplied on the As-free surface or at a minimized excess of arsenic. Under these conditions, $\mathrm{Ga}$ and $\mathrm{Al}$ atoms are expected to migrate along the surface and to find stable sites. The growth rate $r_{\mathrm{g}}$ was determined by measurements of reflection high-energy electron diffraction (RHEED) intensity oscillations from the specular spot. The fluxes of group III (where III $=\mathrm{Ga}$ and $\mathrm{Al}$ ) and $\mathrm{V}(\mathrm{V}=\mathrm{Bi}$ and As) were calculated from the formulae taken from Ref. [11]:

$$
\begin{aligned}
& F_{\mathrm{III}}=\frac{4 r_{\mathrm{g}}}{d^{3}} \\
& F_{\mathrm{V}}=F_{\mathrm{III}} \frac{P_{\mathrm{V}} \cdot \eta_{\mathrm{III}}}{P_{\mathrm{III}} \cdot \eta_{\mathrm{V}}}\left(\frac{T_{\mathrm{V}} \cdot M_{\mathrm{III}}}{T_{\mathrm{III}} \cdot M_{\mathrm{V}}}\right)^{1 / 2} .
\end{aligned}
$$

$d$ in Eq. (1) is the lattice constant of GaAs or AlAs crystals, $P, T, M$ and $\eta$ in Eq. (2) are, respectively, the beam-equivalent pressure (BEP), metallic source temperature, molecular mass, and the ionization efficiency relative to nitrogen. The optimization of AlAs MEE growth parameters, such as $t_{\mathrm{Al}}$ and $t_{\mathrm{As}}$, the time of element supply, and $t_{\text {pause }}$, the pause for migration of $\mathrm{Al}$ on the surface, was carried out at low temperatures ranging from 160 to $350^{\circ} \mathrm{C}$. For MQW growth by MEE the process optimized for GaAsBi with 7\% Bi content was used. A detailed study of Bi incorporation into GaAs using various sequences of $\mathrm{Ga}$, As and Bi supply was analysed and described in our previous work [12].

The growth of MQW was performed at the substrate temperatures from 160 to $350{ }^{\circ} \mathrm{C}$. The substrates were semi-insulating GaAs wafers oriented in the (100) plane. Figure 1 represents the sketch of the multi-quantum well structure and the substrate temperature diagram during the growth by $\mathrm{MBE}$ and MEE. In both types of heterostructures - grown by MBE and MEE - a semi-insulating GaAs(100) 


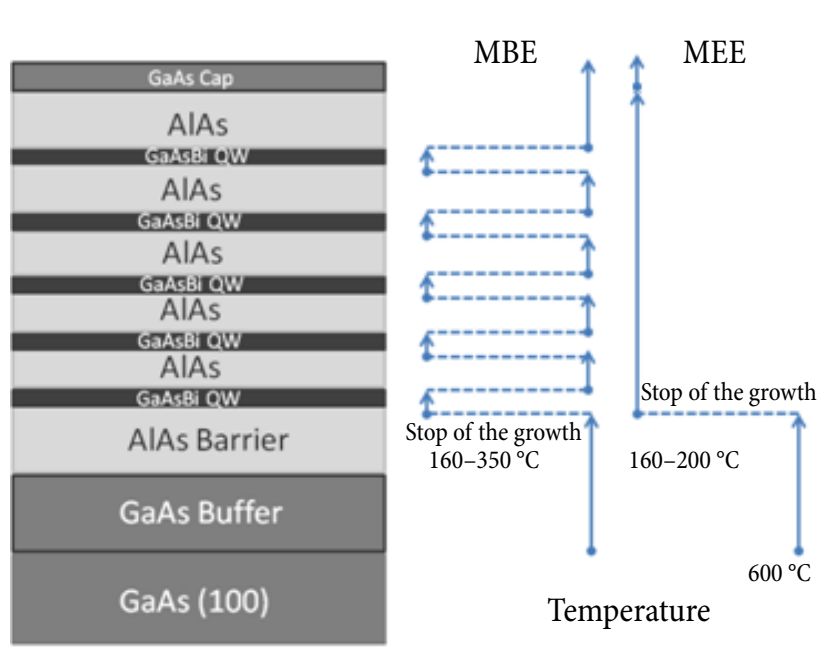

Fig. 1. The multi-quantum well structure consisting of five GaAsBi QWs separated by $20 \mathrm{~nm}$-thick AlAs barriers. The diagram on the right demonstrates the sets of temperature in different stages of the growth of the structure for usual MBE and MEE.

substrate was buffered by the high-temperature GaAs (thickness of about $100 \mathrm{~nm}$ ) and the first high-temperature AlAs barrier (thickness $\sim 20 \mathrm{~nm}$ ) using usual MBE. Then the growth was interrupted for substrate temperature decrease. The number of GaAsBi quantum wells ranged from two to five. QWs were separated by AlAs barriers. The width of quantum wells varied from 4 to $20 \mathrm{~nm}$, the AlAs barrier width was set to 10 and $20 \mathrm{~nm}$. For the MBE growth mode both cladding and internal AlAs barriers were grown at $600{ }^{\circ} \mathrm{C}$, meanwhile MEE of AlAs barriers was performed at the QW growth temperature (see the temperature diagrams for MBE and MEE growth modes on the right side of Fig. 11). Finally, all structures were covered by a $5 \mathrm{~nm}$-thick GaAs capping layer. A part of samples was covered by a GaAs cap at low temperature, the second part of heterostructures was overgrown at $600{ }^{\circ} \mathrm{C}$. The content of $\mathrm{Bi}$ in QWs was about 4 and 7\% growing by MBE and MEE, respectively.

High temperature treatment was performed in a rapid thermal annealing (RTA) oven in the temperature range $650-750{ }^{\circ} \mathrm{C}$ for $180 \mathrm{~s}$ in the nitrogen ambiance. As-grown structures were covered by the GaAs wafer to saturate by an arsenic heating chamber and to prevent As losses from the surface layer.

Technological parameters of the investigated MQW samples are presented in Table 1.

\section{Results and discussion}

\subsection{Structural characterization}

The quality of the crystal structure, the sharpness of the interfaces between GaAsBi QWs and AlAs barriers and the content of $\mathrm{Bi}$ in GaAsBi quantum wells were determined by measuring high-resolution $\mathrm{X}$-ray diffraction (HRXRD). HRXRD $\omega-2 \theta$ scans were measured using a SmartLab diffractometer (Rigaku) with a monochromatic $\mathrm{CuK} \alpha \mathrm{X}$-ray source. Figure 2 shows the HRXRD $\omega-2 \theta$ scans of the (002) reflex measured for the $5 \times\{\mathrm{GaAsBi} / \mathrm{AlAs}\}$ QW structure (sample B633) as-grown (Fig. 2(a)) by MBE and annealed (Fig. 2(b)). The apparent Pendellösung fringes in Fig. 2(a) demonstrate the epitaxial growth of the structure with very sharp interfaces between the layers even at $200{ }^{\circ} \mathrm{C}$ growth temperature. The width of GaAsBi QWs and AlAs barriers evaluated from the XRD scan simulation (grey curve in Fig. 2(a)) was 4 and $20 \mathrm{~nm}$, respectively. As a consequence of the high temperature (HT) treatment at $750{ }^{\circ} \mathrm{C}$ (measurement represented by a black curve in Fig. 2(b)), the increase of intensity and a slight shift of the reflex from GaAsBi QWs towards GaAs suggest improvement of the crystal quality of the quantum well and an insignificant decrease

Table 1. Main parameters of multi-quantum structures as-grown and thermally treated: $N_{\mathrm{QW}}$ is the number of GaAsBi quantum wells; $d_{\mathrm{QW}}$ and $T_{\mathrm{QW}}$ are the width and growth temperature of the quantum well; $d_{\text {barrier }}$ and $T_{\text {barrier }}$ are the width and growth temperature of the AlAs barrier; $T_{\text {cap }}$ is the growth temperature of the capping layer; the growth modes MBE or MEE are molecular beam epitaxy and migration-enhanced epitaxy, respectively.

\begin{tabular}{|c|c|c|c|c|c|c|c|}
\hline Sample & $N_{\text {QW }} \mathrm{nm}$ & $d_{\text {QW }} \mathrm{nm}$ & $d_{\text {barier }} \mathrm{nm}$ & $T_{\mathrm{QW}}{ }^{\circ} \mathrm{C}$ & $T_{\text {barrier }}{ }^{\circ} \mathrm{C}$ & $T_{\text {cap }}{ }^{\circ} \mathrm{C}$ & Growth mode \\
\hline B631 & 2 & 6 & 20 & 350 & 350 & 600 & MBE \\
\hline B633 & 5 & 4 & 20 & 200 & 600 & 600 & MBE \\
\hline B638 & 5 & 4 & 20 & 160 & 160 & 160 & MEE \\
\hline B652 & 3 & 4 & 20 & 200 & 200 & 600 & MBE \\
\hline B675 & 1 & 20 & 10 & 200 & 200 & 200 & MEE \\
\hline
\end{tabular}



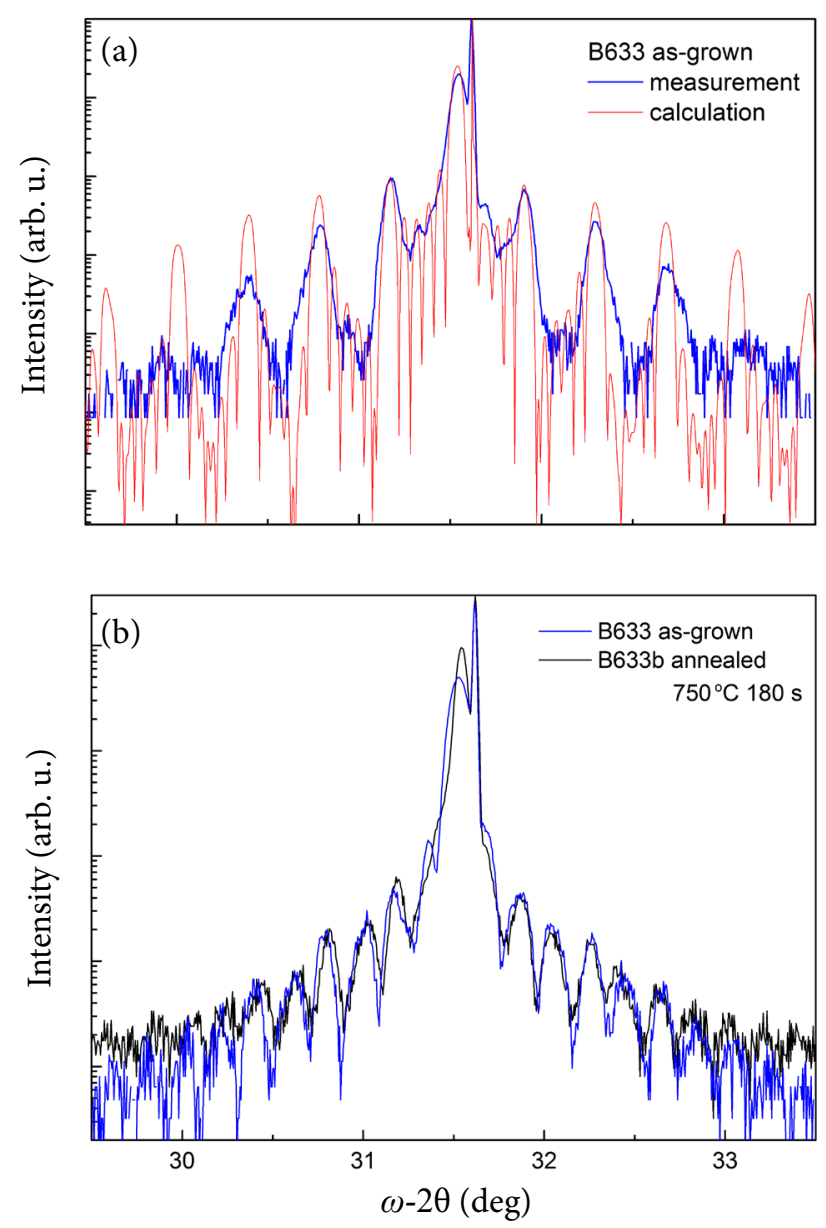

Fig. 2. HRXRD $\omega-2 \theta$ scans of the (002) reflex measured for the $5 \times\{\mathrm{GaAsBi} / \mathrm{AlAs}\}$ quantum well structure grown at $200{ }^{\circ} \mathrm{C}$ temperature by MBE and annealed at $750{ }^{\circ} \mathrm{C}$ temperature (sample B633). The upper scan (a) presents the measurements of the as-grown structure (red line online), the blue line shows the results of simulation. The scans demonstrated in the plot (b) were measured for the MQWs structure before and after annealing at $750{ }^{\circ} \mathrm{C}$ for $180 \mathrm{~s}$.

of the Bi content in the lattice. Moreover, one can see from Fig. $6(\mathrm{~b})$ that the HT annealing procedure does not destroy the sample; the visible fringes point to a layered structure with the same QW and barrier width. The small reduction of Bi content in the GaAsBi quantum well and the sharp interfaces allow us to suppose that AlAs grown at low temperature using MEE acts as a Bi blocking layer.

\subsection{Surface morphology}

The surfaces of samples were investigated by a scanning probe microscope (SPM) Dimension 3100/Nanoscope IVa (Veeco Metrology Group). Images were acquired in the tapping mode using TESP-V2 (Bruker) probes with a tip curvature about $8 \mathrm{~nm}$.
Figure 3 illustrates the surface morphology of the GaAs capping layer of the MQW structure grown by $\mathrm{MBE}$ at $350{ }^{\circ} \mathrm{C}$ temperature and then capped at $600{ }^{\circ} \mathrm{C}$ (Fig. 3(a) is sample B631); Fig. 3(b) presents the surface of MEE grown at the $160{ }^{\circ} \mathrm{C}$ GaAs cap (sample B638). MBE grown GaAsBi MQWs with AlAs barriers deposited at the same temperature or at $600{ }^{\circ} \mathrm{C}$ demonstrated very smooth surfaces. The surface roughness of these samples was about few tens of nanometre. It should be noted that several MBE grown samples (with larger Bi content) demonstrated some crystal features on the surface of the GaAs cap - pits in height of about 5-10 nm (see Fig. 3(a)), related to the lack of As during the growth of LT-AlAs; this could mean that the MBE growth of AlAs at low temperatures is more sensitive to the As flux than using MEE. On the other hand, the morphology of structures grown by MEE at significantly lower temperatures $\left(160-200{ }^{\circ} \mathrm{C}\right)$ showed the multidispersive crystal quality of the GaAs cap. The surface roughness of the capping GaAs layer was higher for the MEE grown structure but not exceeded
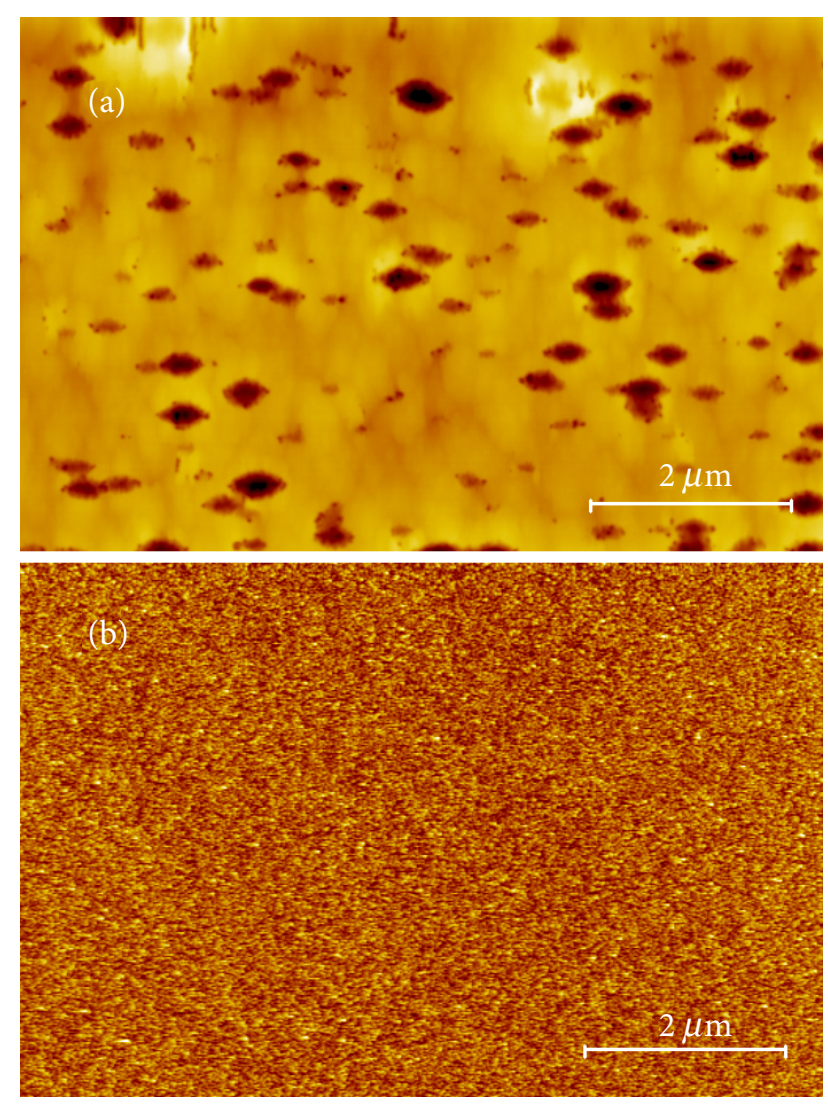

Fig. 3. Surface topography maps of MQWs grown by $\mathrm{MBE}$ (sample B631) at substrate temperature of $350{ }^{\circ} \mathrm{C}$ (a) and by MEE (sample B638) grown at $160{ }^{\circ} \mathrm{C}$ (b). Scanned areas are $8 \times 5.3 \mu \mathrm{m}, \mathrm{z}$-scale is $62 \mathrm{~nm}$ for (a) and $15 \mathrm{~nm}$ for (b). 
$1 \mathrm{~nm}$. After annealing at $750{ }^{\circ} \mathrm{C}$ for $180 \mathrm{~s}$ the AFM images of both MBE and MEE grown samples demonstrated a droplets-free surface supporting the hypothesis that AlAs barriers stop the Bi out-diffusion from the QW.

\subsection{Raman spectroscopy investigation}

Raman spectra were recorded using an inVia Raman (Renishaw, United Kingdom) spectrometer equipped with a thermoelectrically cooled $\left(-70^{\circ} \mathrm{C}\right) \mathrm{CCD}$ camera and a microscope. The samples were excited with $532 \mathrm{~nm}$ radiation from a diode-pumped solid-state laser. $50 \times 0.75 \mathrm{NA}$ objective lens and 1800 lines $/ \mathrm{mm}$ grating were used to record the Raman spectra. The accumulation time was $400 \mathrm{~s}$. To avoid damage of the sample, the laser power was limited to $0.06 \mathrm{~mW}$. The Raman frequencies were calibrated using the silicon standard according to the line at $520.7 \mathrm{~cm}^{-1}$. Parameters of the bands were determined by fitting the experimental spectra with Gaussian-Lorentzian shape components using the GRAMS/A1 8.0 (Thermo Scientific) software.

The analysis of the Raman spectra measured for both MBE and MEE grown MQWs revealed an intense doublet at 269 and $290 \mathrm{~cm}^{-1}$ attributed to transverse optical (TO) and longitudinal optical (LO) phonon modes of the GaAs-like structure, respectively, as well as a sharp LO mode at $402 \mathrm{~cm}^{-1}$ from AlAs barriers [13-17]. The samples showed the Bi-induced disorder in the crystal activating the band near $269 \mathrm{~cm}^{-1}$ and two other broad Bi-induced vibrational modes visible near 227 and $181 \mathrm{~cm}^{-1}$. After annealing, the changes at low frequency bands at 72 and $96 \mathrm{~cm}^{-1}$ were explained by formation of crystalline bismuth nanoparticles. Moreover, the Raman spectra of MBE grown samples with LT-AlAs barriers (see Fig. 4 (a), sample B652) and annealed ones (Fig. 4(b)) revealed a different effect of annealing on the crystalline structure of AlAs barriers compared to the MEE grown sample (not presented in this paper). AlAs barriers in the $\mathrm{MBE}$ as-grown sample can be recognized from the medium-intensity unresolved band near $400 \mathrm{~cm}^{-1}$ which belongs to the LO vibrational mode (Fig. $4(\mathrm{a})$ ). The defect-induced TO mode of AlAs is visible near $362 \mathrm{~cm}^{-1}$. It is interesting that the intensity of AlAs modes in the MBE grown sample dramatically increases after annealing, meanwhile the changes in the Raman spectrum of MEE grown AlAs are negligible. In addition, the frequency of the LO mode decreases from 400 to $388 \mathrm{~cm}^{-1}$ indicating considerable structural changes within the AlAs layers, meanwhile the intensities of GaAs and Bi-induced vibrational modes remain unchanged. The increase in Raman

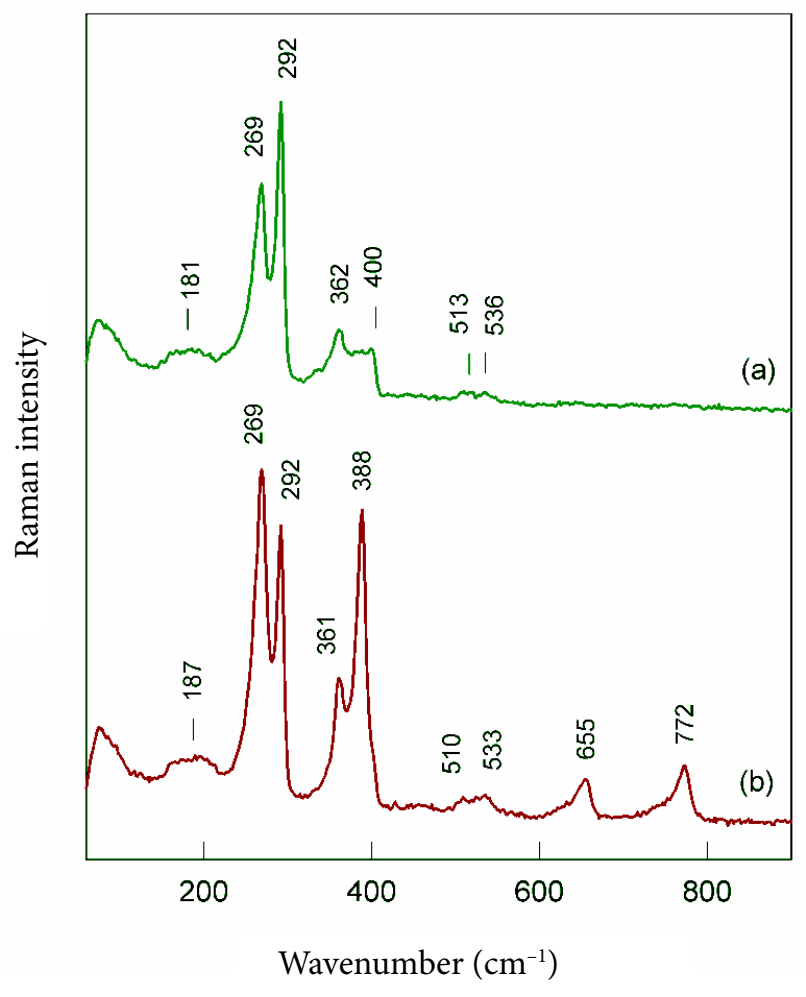

Fig. 4. Raman spectra of sample B652 before (a) and after thermal annealing at $750{ }^{\circ} \mathrm{C}$ for $180 \mathrm{~s}$ (b). Excitation wavelength is $532 \mathrm{~nm}(0.06 \mathrm{~mW})$.

intensity might be associated with the improved crystalline order in MBE LT-grown AlAs barriers.

\subsection{HRTEM investigation}

The high-resolution microstructure and chemical composition of as-grown and annealed MQWs were measured using a FEI Tecnai G2 F20 X-TWIN TEM with the STEM module, associated with an X-ray energy dispersive spectroscopy (EDS) detector for elemental mapping and a high angle annular darkfield (HAADF) detector for Z-contrast imaging. A FEI Helios Nanolab 650 dual beam microscope equipped with an Omniprobe manipulator was used to prepare specimens in order to analyse the crosssectional microstructure of MQWs. The focused ion beam microscope was operated with a $5 \mathrm{kV}$ electron beam and a $30 \mathrm{kV} \mathrm{Ga}^{+}$ion beam. To protect the sample from an incident ion beam bombardment, a platinum protection cap of approximately $2 \mu \mathrm{m}$ thickness was deposited on the surface by DC sputtering.

The corresponding EDS elemental mapping results obtained for the GaAsBi-based heterostructure as-grown by MEE and annealed at $750{ }^{\circ} \mathrm{C}$, containing a $20 \mathrm{~nm}$-thick single quantum well sandwiched between $20 \mathrm{~nm}$ AlAs barriers (sample B675) presented in Fig. 5. The rectangular frame on the HAADF 

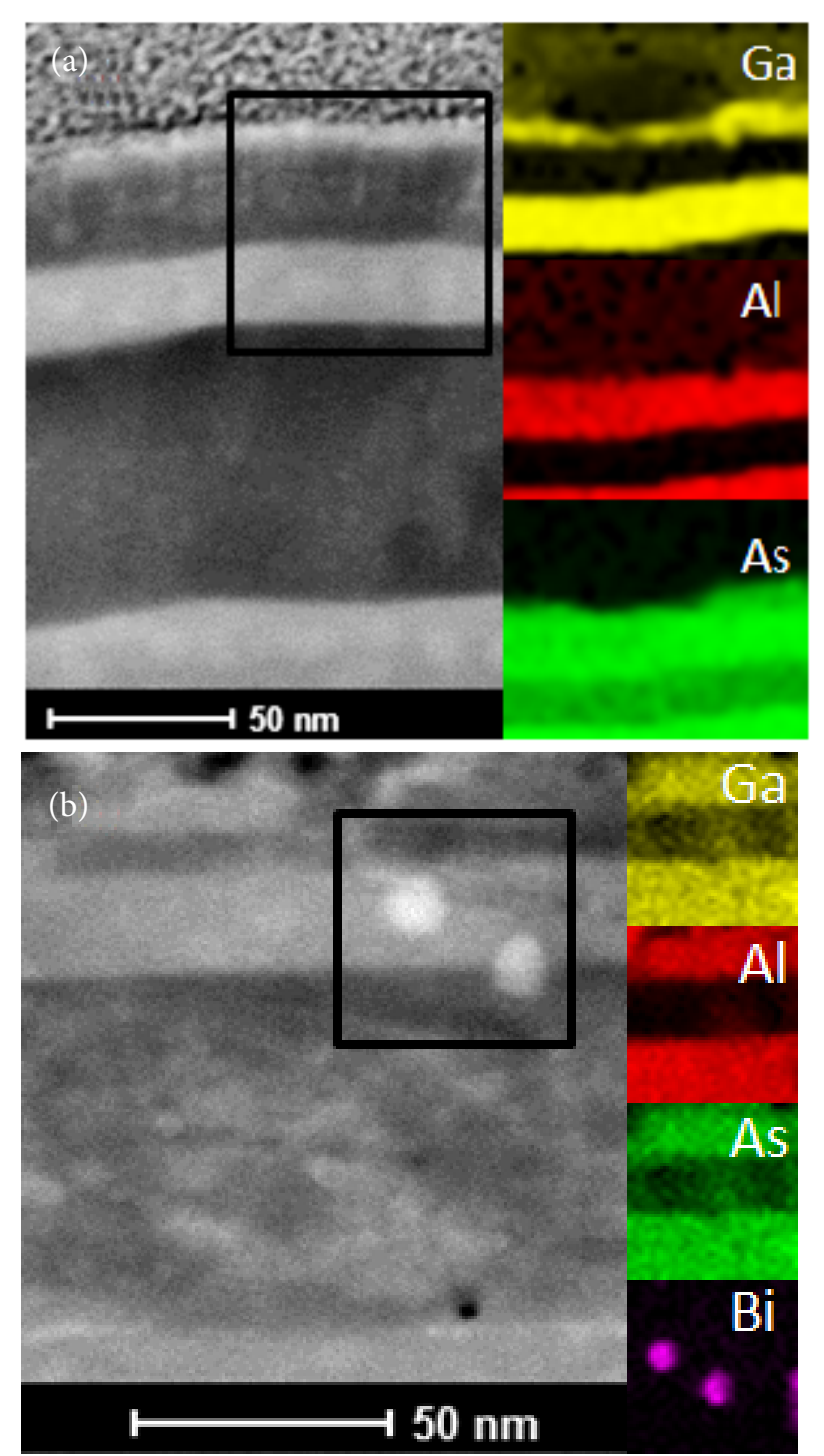

Fig. 5. The HAADF image of single QW structures consisting of a $20 \mathrm{~nm} \mathrm{GaAsBi}$ quantum well and a $20 \mathrm{~nm}$ thick AlAs barrier on the top of the well (sample B675) grown by MEE at $200{ }^{\circ} \mathrm{C}$ temperature: as-grown (a) and annealed (b). The EDS images represent $\mathrm{Ga}, \mathrm{Al}$, As and Bi elemental maps of two locations on the TEM image marked by frame.

image of the cross-section demonstrates the area of $\mathrm{X}$-ray energy dispersive spectra measurements. Various colours (yellow corresponds to $\mathrm{Ga}$, red is $\mathrm{Al}$, green is As, and violet is $\mathrm{Bi}$ ) in EDS elemental mapping represent different chemical elements - $\mathrm{Ga}, \mathrm{Al}$, As, and $\mathrm{Bi}$ - in the studied field. From the analysis of histograms it follows that sharp interfaces between GaAsBi QWs and AlAs barriers are obvious for both as-grown (Fig. 5(a)) and annealed (Fig. 5(b)) MQWs. No traces of Bi segregation through the top barrier are visible in the pictures. The aggregation of bismuth atoms to nano-scale particles in the QWs, shown in Fig. 5(b), shows that the upper AlAs barrier acts like a blocking layer for out-diffusion of Bi. Similar results of HRTEM investigation were obtained for MBE grown heterostructures.

Figure 6 shows the cross-sectional HRTEM bright field images of the GaAsBi quantum well and the crystalline AlAs barrier on the top with the corresponding fast Fourier transform (FFT) diffractograms on the right side obtained for the heterostructure asgrown by MEE (a) and annealed at $750{ }^{\circ} \mathrm{C}(\mathrm{b})$. A guide for the eye, the interface between the QW and barrier is marked by a dotted line. It can be deduced from the images that both the quantum well and the barrier exhibit epitaxial growth. Moreover, the less dispersive background of the electron diffraction FFT image shows the higher crystalline order of AlAs after annealing, and gives us an additional confirmation of epitaxial growth of barriers at extremely low temperature.

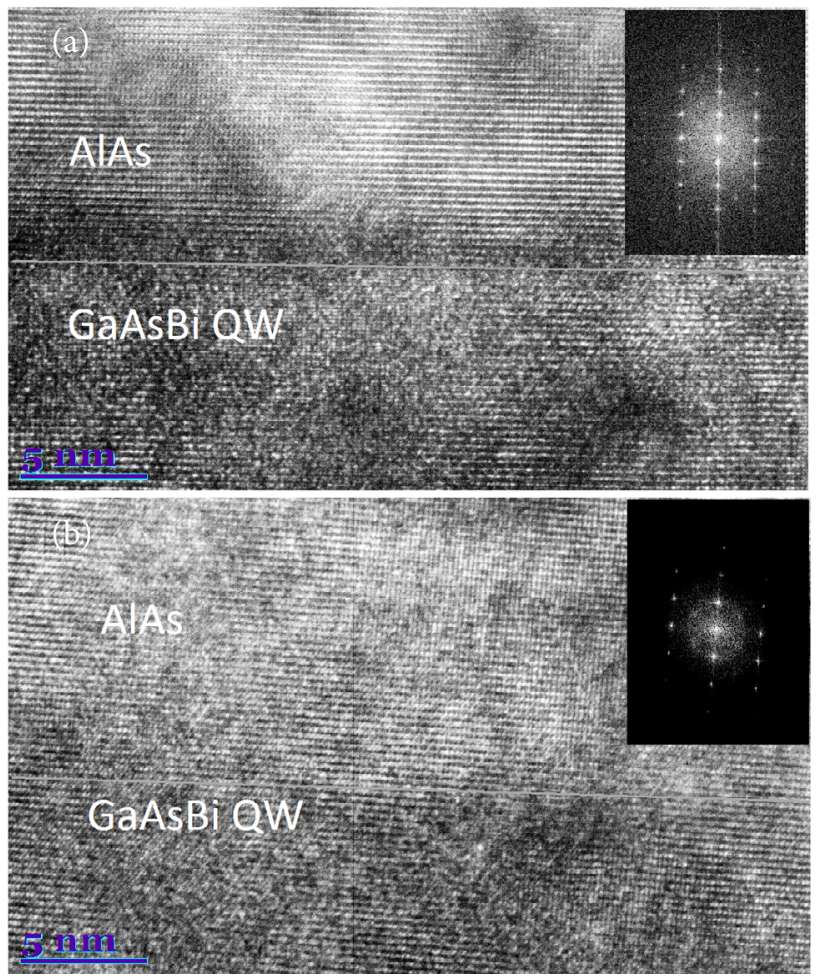

Fig. 6. HRTEM bright field mode images of the crosssection of sample B675: (a) as-grown by MEE QW structure and (b) annealed at $750{ }^{\circ} \mathrm{C}$ for $180 \mathrm{~s}$. The scale bar in both cross-section images is $5 \mathrm{~nm}$.

\section{Conclusions}

The GaAsBi-based multi-quantum well structures with AlAs barriers were grown on GaAs substrates by molecular beam epitaxy and migration-enhanced epitaxy. The growth of MQW structures was performed at substrate temperatures from 160 to 
$350{ }^{\circ} \mathrm{C}$. The substrates were semi-insulating GaAs wafers oriented in the (100) plane. The width of GaAsBi quantum wells varied from 4 to $20 \mathrm{~nm}$. The optimization of technological parameters for the growth of high crystalline quality AlAs barriers at low as well as at high temperatures was performed. Ex situ rapid thermal annealing was performed for all samples at $750{ }^{\circ} \mathrm{C}$ temperature for $180 \mathrm{~s}$ in nitrogen ambience. It was demonstrated by HRXRD measurements that MEE allows one to achieve higher crystal quality of AlAs barriers at much lower temperatures $\left(160-200^{\circ} \mathrm{C}\right)$ in comparison to $\mathrm{MBE}\left(200-350^{\circ} \mathrm{C}\right)$. The study of samples by Raman spectroscopy revealed that the intensity of AlAs modes dramatically increased after annealing of MBE grown MQWs, thus leading to the improved barrier crystal quality. The HRTEM EDS elemental mapping showed the blocking of Bi out-diffusion from the GaAsBi quantum well toward the surface for both MBE and MEE grown MQWs with AlAs barriers.

\section{Acknowledgements}

This research was financially supported by the Research Council of Lithuania under Contract No. MIP-71/2015 (BiNano; Bismuth quantum dots in GaAs matrix).

\section{References}

[1] K. Oe and H. Okamoto, New semiconductor alloy $\mathrm{GaAs}_{1-x} \mathrm{Bi}_{x}$ grown by metal organic vapor phase epitaxy, Jpn. J. Appl. Phys. 37, L1283 (1998).

[2] S. Francoeur, M.J. Seong, A. Mascarenhas, S. Tixier, M. Adamcyk, and T. Tiedje, Band gap of $\mathrm{GaAs}_{1-x} \mathrm{Bi}_{x}$, $0<x<3.6 \%$, Appl. Phys. Lett. 82, 3874 (2003).

[3] X. Lu, D.A. Beaton, R.B. Lewis, T. Tiedje, and Y. Zhang, Composition dependence of photoluminescence of $\mathrm{GaAs}_{1-x} \mathrm{Bi}_{x}$ alloys, Appl. Phys. Lett. 95, 041903 (2009).

[4] J. Devenson, V. Pačebutas, R. Butkutè, A. Baranov, and A. Krotkus, Structure and optical properties of InGaAsBi with up to 7\% bismuth, Appl. Phys. Express 5, 015503 (2012).

[5] R. Butkutè, V. Pačebutas, B. Čechavičius, R. Nedzinskas, A. Selskis, A. Arlauskas, and A. Krotkus, Photoluminescence at up to $2.4 \mu \mathrm{m}$ wavelengths from GaInAsBi/AlInAs quantum wells, J. Cryst. Growth 391, 116-120 (2014).

[6] E. Luna, M. Wu, M. Hanke, J. Puustinen, M. Guina, and A. Trampert, Spontaneous formation of three-dimensionally ordered Bi-rich nanostructures within $\mathrm{GaAs}_{1-x} \mathrm{Bi}_{x} / \mathrm{GaAs}$ quantum wells, Nanotechnology 27, 32 (2016).

[7] R. Butkutè, V. Pačebutas, B. Čechavičius, R. Adomavičius, A. Koroliov, and A. Krotkus, Thermal annealing effect on the properties of GaBiAs, Phys. Status Solidi C 9(7), 1614-1616 (2012).

[8] R. Butkutè, K. Stašys, V. Pačebutas, B. Čechavičius, R. Kondrotas, A. Geižutis, and A. Krotkus, Bismuth quantum dots and strong infrared photoluminescence in migration-enhanced epitaxy grown GaAsBi-based structures, Opt. Quant. Electron. 47, 873-882 (2015).

[9] T. Kawai, H. Yonezu, H. Yoshida, and K. Pak, Ge segregation and its suppression in GaAs epilayers grown on Ge(lll) substrate, Appl. Phys. Lett. 61, 1216 (1992).

[10] C.K. Chia, J.R. Dong, D.Z. Chi, A. Sridhara, A.S.W. Wong, M. Suryana, G.K. Dalapati, S.J. Chua, and S.J. Lee, Effects of AlAs interfacial layer on material and optical properties of $\mathrm{GaAs} / \mathrm{Ge}(100)$ epitaxy, Appl. Phys. Lett. 92, 141905 (2008).

[11]G.J. Davies and D. Williams, The Technology and Physics of Molecular Beam Epitaxy, ed. E.H.C. Parker (Plenum Press, New York, 1985).

[12] R. Butkutè, V. Pačebutas, A. Krotkus, N. Knaub, and K. Volz, Migration-enhanced epitaxy of thin GaAsBi layers, Lith. J. Phys. 54(2), 125-129 (2014).

[13] F. Sarcan, O. Dönmez, K. Kara, A. Erol, E. Akalin, M.C. Arikan, H. Makhlouf, A. Arnoult, and C. Fontaine, Bismuth-induced effects on optical, lattice, and structural properties of bulk GaAsBi alloys, Nanoscale Res. Lett. 9, 119 (2014).

[14] J.A. Steele, R.A. Lewis, J. Horvat, M.J.B. Nancarrow, M. Henini, D. Fan, Y.I. Mazur, M. Schmidbauer, M.E. Ware, S.-Q. Yu, and G.J. Salamo, Surface effects of vapour-liquid-solid driven Bi surface droplets formed during molecular-beam-epitaxy of GaAsBi, Sci. Rep. 6, 28860 (2016).

[15] P. Verma, K. Oe, M. Yamada, H. Harim, M. Herms, and $\mathrm{G}$. Irmer, Raman studies on $\mathrm{GaAs}_{1-x} \mathrm{Bi}_{x}$ and InAs $s_{1-x} \mathrm{Bi}_{x^{\prime}}$ J. Appl. Phys. 89, 1657-1663 (2001).

[16] M.J. Seong, S. Francoeur, S. Yoon, A. Mascarenhas, S. Tixier, M. Adamcyk, and T. Tiedje, Bi-induced vibrational modes in GaAsBi, Superlattices Microstruct. 37, 394-400. (2005).

[17] G.S. Spencer, J. Menéndez, L.N. Pfeiffer, and K.W. West, Optical-phonon Raman-scattering study of short-period GaAs-AlAs superlattices: An examination of interface disorder, Phys. Rev. B 52, 8205-8218 (1995). 


\title{
Bi DIFUZIJA BLOKUOJANTYS AlAs BARJERAI GaAsBi KVANTINIUOSE DARINIUOSE: STRUKTŪRINIS CHARAKTERIZAVIMAS
}

\author{
R. Butkute a , M. Skapas ${ }^{\text {b }}$, A. Selskis ${ }^{\text {b }}$, V. Bukauskas ${ }^{\text {a }}$, S. Stanionytė ${ }^{\text {a, b }}$, G. Niaura ${ }^{\text {c }}$

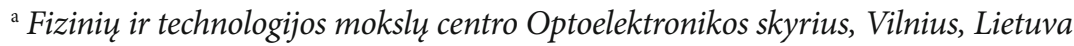

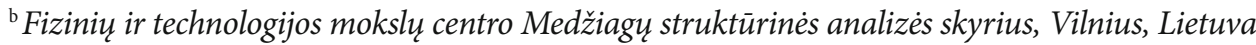 \\ ${ }^{c}$ Fiziniu ir technologijos mokslu centro Organinès chemijos skyrius, Vilnius, Lietuva
}

\begin{abstract}
Santrauka
Pristatomas kristalografinių AlAs barjerų GaAsBi junginio pagrindu daugybinių kvantinių duobių, užaugintų ant GaAs padèkliukų molekulinių pluoštelių epitaksijos ir atomų migraciją paskatinančios epitaksijos būdais, savybių tyrimas. Kvantinès duobès buvo auginamos nuo 160 iki $350^{\circ} \mathrm{C}$ temperatūrose. Tiriamajame darbe ju plotis kito nuo 4 iki $20 \mathrm{~nm}$. Siekiant sustabdyti Bi segregaciją iš kvantinès duobès link bandinio paviršiaus dariniuose vietoj ịprastinių GaAs barjerų pasirinktas AlAs. Atliekant technologinių parametrų paiešką auginimai atlikti tiek žemose, bismidams būtinose temperatūrose, tiek ir aukštose, $600{ }^{\circ} \mathrm{C}$ siekiančiose temperatūrose. Surastos optimalios AlAs barjerų auginimo technologinès sąlygos. Darbe detaliai pateikta barjerų auginimo parametrų ir vèliau atlikto kaiti-
\end{abstract}

nimo $750{ }^{\circ} \mathrm{C}$ temperatūroje $180 \mathrm{~s}$ azoto aplinkoje įtaka kristalinei AlAs sandarai, paviršiaus šiurkštumui, daugiasluoksnio kvantinio darinio sąlyčio riboms ir cheminei sudèčiai. Tyrimai atlikti didelès skyros rentgeno spindulių difrakcijos, atominių jègu mikroskopijos ir didelès skyros peršviečiamosios elektronų mikroskopijos metodais. Atskleista, kad pasitelkus atomų migraciją paskatinančią epitaksiją galima užauginti ypač aukštos kristalinès kokybès AlAs barjerus esant daug žemesnei nei molekulinių pluoštelių epitaksijos atveju auginimo temperatūrai. Taip pat pademonstruota, kad ir molekulinių pluoštelių epitaksija, ir atomų migraciją skatinanti epitaksija, kai jų veikimo metu sudaromos optimalios auginimo sąlygos, gali būti taikomos Bi segregaciją iš GaAsBi kvantinių duobių stabdantiems AlAs barjerams auginti. 